OPEN ACCESS

Edited by:

Ivan Baccelli,

Istituto per la Protezione Sostenibile

delle Piante, Sede Secondaria

Firenze, Italy

Reviewed by:

Marie-Claire Goulet,

Laval University, Canada

Patricia Castro,

Universidad de Córdoba, Spain

*Correspondence:

David Turrà

davturra@unina.it

Matteo Lorito

lorito@unina.it

Specialty section: This article was submitted to

Plant Microbe Interactions,

a section of the journal

Frontiers in Plant Science

Received: 27 September 2019

Accepted: 27 March 2020

Published: 30 April 2020

Citation:

Turrà D, Vitale S, Marra R, Woo SL and Lorito M (2020) Heterologous

Expression of PKPI and Pin 1

Proteinase Inhibitors Enhances Plant

Fitness and Broad-Spectrum

Resistance to Biotic Threats.

Front. Plant Sci. 11:461.

doi: 10.3389/fpls.2020.00461

\section{Heterologous Expression of PKPI and Pin1 Proteinase Inhibitors Enhances Plant Fitness and Broad-Spectrum Resistance to Biotic Threats}

\author{
David Turrà ${ }^{1 *}$, Stefania Vitale ${ }^{1}$, Roberta Marra ${ }^{1,2}$, Sheridan L. Woo ${ }^{2,3,4}$ and \\ Matteo Lorito ${ }^{1,2,3 *}$
}

\begin{abstract}
${ }^{1}$ Department of Agricultural Sciences, University of Naples Federico II, Naples, Italy, ${ }^{2}$ Task Force on Microbiome Studies, University of Naples Federico II, Naples, Italy, ${ }^{3}$ Institute for Sustainable Plant Protection, National Research Council, Naples, Italy, ${ }^{4}$ Department of Pharmacy, University of Naples Federico II, Naples, Italy
\end{abstract}

Kunitz-type (PKPI) and Potato type I (Pin1) protease inhibitors (PIs) are two families of serine proteinase inhibitors often associated to plant storage organs and with well known insecticidal and nematicidal activities. Noteworthy, their ability to limit fungal and bacterial pathogenesis in vivo or to influence plant physiology has not been investigated in detail. To this aim, we generated a set of PVX-based viral constructs to transiently and heterologously express two potato PKPI (PKI1, PKI2) and three potato Pin1 (PPI3A2, PPI3B2, PPI2C4) genes in Nicotiana benthamiana plants, a widely used model for plant-pathogen interaction studies. Interestingly, transgenic plants expressing most of the tested Pls showed to be highly resistant against two economically important necrotrophic fungal pathogens, Botrytis cinerea and Alternaria alternata. Unexpectedly, overexpression of the PKI2 Kunitz-type or of the PPI2C4 and PPI3A2 Potato type I inhibitor genes also lead to a dramatic reduction in the propagation and symptom development produced by the bacterial pathogen Pseudomonas syringae. We further found that localized expression of PPI2C4 and PKI2 in $N$. benthamiana leaves caused an increase in cell expansion and proliferation which lead to tissue hypertrophy and trichome accumulation. In line with this, the systemic expression of these proteins resulted in plants with enhanced shoot and root biomass. Collectively, our results indicate that PKPI and Pin1 PIs might represent valuable tools to simultaneously increase plant fitness and broad-spectrum resistance toward phytopathogens.

Keywords: Pin1, PKPI, plant cell proliferation, Pseudomonas syringae, Alternaria alternata, Botrytis cinerea, disease resistance 


\section{INTRODUCTION}

PKPI and Pin1 are among the most abundant naturally occurring plant serine proteinase inhibitors (PIs). Large amounts of these inhibitors accumulate in plant reproductive and storage organs, as in the case of Solanum tuberosum (Heibges et al., 2003; van den Broek et al., 2004). Nevertheless, their genes are also transcribed, however at lower levels, in all other plant tissues (Kuo et al., 1984; Lincoln et al., 1987; Jofuku and Goldberg, 1989; Heitz et al., 1993; Wang et al., 2003, 2008; Turrà et al., 2009). Serine PIs expression apart from being regulated at developmental, spatial and speciesspecific level (Lee et al., 1986; Rosahl et al., 1986; Balandin et al., 1995; Singh et al., 2009; Tamhane et al., 2009; Turrà et al., 2009), is boosted up by various external stimuli including wounding, insect feeding and microbial infections (Mello et al., 2001; van Loon et al., 2006; Turrà and Lorito, 2011), being one of the bestcharacterized defense reactions activated by the plant in response to pathogen and insect attack. Many studies on the effect of serine PIs, either artificially introduced into diets or heterologously expressed in transgenic plants, have shown the ability of these proteins to reduce the growth and development of a wide range of herbivorous insects and pathogenic nematodes mainly by interfering with nutrient digestibility and fertility (Jongsma et al., 1995; Urwin et al., 1995; Altpeter et al., 1999; Andrade et al., 2003; Cai et al., 2003; Srinivasan et al., 2005).

Besides, few serine PIs have also shown inhibitory activity against bacteria and fungi in vitro by reducing their growth or conidial germination and hyphal swelling, respectively (Lorito et al., 1994; Dunaevsky et al., 1996; Chen et al., 1999; SoaresCosta et al., 2002; Kim et al., 2005; Hermosa et al., 2006; Kim et al., 2006; Di Cera, 2009). However, while serine PIs insecticidal and nematicidal activities have been efficiently proven in planta, their ability to alter plant resistance against fungal or bacterial pathogens in vivo has remained elusive.

Proteases and PIs play important roles in plant-pathogen interactions; nevertheless, testimony for their endogenous role in plants is relatively recent and our current understanding of the diverse physiological processes regulated by PIs is rapidly expanding (van der Hoorn, 2008; Turrà and Lorito, 2011; GrosseHolz and van der Hoorn, 2016). To date, protease-PI interactions have been shown to regulate many diverse aspects of the plant life cycle including senescence and programmed cell death (PCD), leaf trichome density and branching, seed and flower development and sieve element maturation (Solomon et al., 1999; Xu et al., 2001; Sin and Chye, 2004; Pak and Van Doorn, 2005; Liu et al., 2006; Xie et al., 2007; Luo et al., 2009; Boex-Fontvieille et al., 2015; Rustgi et al., 2017).

As proteolysis is a fundamental process in all living beings, in order to avoid undesired side-effects plants must carefully control endogenous protease activity in both a timely and a spatial manner (van der Hoorn, 2008; Turrà and Lorito, 2011). In a previous work from our group, we have shown that PI gene members of the Pin 1 and PKPI families are differentially expressed in Solanum tuberosum var. Desireè plants upon abiotic or biotic insults, or in a tissue-dependent manner, thus indicating a possible role for these PIs as both endogenous- and defenserelated plant regulators (Turrà et al., 2009).
In this study, the effect of transient expression of different members of the Pin 1 and PKPI families on plant resistance toward fungal and bacterial pathogens and on plant physiology is reported. When heterologously expressed in Nicotiana benthamiana, different potato PKPI and Pin1 genes confer protection against $B$. cinerea and A. alternata, two agronomically important pathogens. Moreover, in vivo assays designed to challenge PIs-expressing plants with Pseudomonas syringae pv. tabaci also revealed enhanced plant resistance to bacterial attack. In addition to this, overexpression of two of these serine PI genes also caused severe developmental effects on $N$. benthamiana plants, including over-accumulation of trichomes and growth enhancement. These phenotypes were accompanied by the high inhibitory activity of total soluble proteins (TSP) extracted from transformed leaf patches toward yet unknown proteases present in the N. benthamiana leaf apoplast. Based on these results, we propose that Pin 1 and PKPIs are critically involved in host resistance and modulation of plant physiology.

\section{MATERIALS AND METHODS}

\section{Microbial Strains, Plants, and Culture Conditions}

Nicotiana benthamiana plants were cultivated and maintained at $25^{\circ} \mathrm{C}$ in a phytocabinet under $16 / 8 \mathrm{~h}$ light-dark photoperiod.

Agrobacterium tumefaciens GV3101, Escherichia coli DH5 $\alpha$ and a rifampicin-resistant strain of $P$. syringae pv. tabaci were routinely grown in Luria-Bertani (LB) media (Sambrook and Russell, 2001) with appropriate antibiotics at $28^{\circ} \mathrm{C}, 37^{\circ} \mathrm{C}$, or $28^{\circ} \mathrm{C}$, respectively. All bacterial DNA transformations were performed by electroporation using standard protocols (Sambrook and Russell, 2001).

Conidia of the pathogenic fungi $B$. cinerea and A. alternata were harvested respectively from malt extract peptone agar (MEP) (Difco, Detroit, MI, United States) or potato dextrose agar (PDA) (Sigma-Aldrich, St. Louis, MO, United States) plates, after 1 week of incubation at $25^{\circ} \mathrm{C}$, as previously described (Hermosa et al., 2006).

\section{Construction of PVX::PI Gene Fusions}

To amplify full-length cDNAs of PKI1, PKI2, PPI3A2, PPI3B2, and PPI2C4 genes (Hermosa et al., 2006; Turrà et al., 2009), total RNA was extracted from $100 \mathrm{mg}$ of Solanum tuberosum var. Desireè sprouts using the TRI Reagent (Ambion, Austin, TX, United States). First-strand cDNA was synthesized using the Reverse Transcription System kit (Promega, Madison, WI, United States) and $1 \mu \mathrm{g}$ random primers for every $2 \mu \mathrm{g}$ of total RNA, following the supplier's instructions. The PKPI and Pin 1 derivatives were amplified by PCR using the oligonucleotide combinations indicated in Supplementary Table S1, subcloned into pGEM-T Easy vector (Promega), and ligated into the ClaI and SalI sites of the A. tumefaciens binary PVX vector pGR106 (Lu et al., 2003).

Constructs containing the inserts in sense orientation were designated PVX::PKI1, PVX::PKI2, PVX::PPI3A2, PVX::PPI3B2, and PVX::PPI2C4. The obtained binary vectors, the pGR106 
vector without any insert and the pGR208 vector (Rairdan et al., 2008), $g f p$ cDNA ligated in the same vector, were transformed into A. tumefaciens strain GV3101. pGR106 and pGR208 vectors were used as PVX controls.

\section{Transient Expression of Pls Genes in $N$. benthamiana and in vivo Resistance Assay on PVX-Infected Plants}

$N$. benthamiana seedlings at the fourth true-leaf stage were used for A. tumefaciens infiltration. To evaluate local effects of PI overexpression, A. tumefaciens overnight cultures diluted to an OD600 of 0.25 with sterile distilled water were used to infiltrate the abaxial side of the leaf (using a needleless $5 \mathrm{ml}$ syringe). Alternatively, to achieve systemic transformation of plants, third and fourth leaves of 2-3-week-old $N$. benthamiana seedlings were wounded twice along the midvein with a sterile wooden toothpick previously streaked over an A. tumefaciens culture grown on solid agar medium.

For $P$. syringae infection, 5 days after $A$. tumefaciens syringeinfiltration, the same leaf areas were infiltrated (the abaxial side of the leaf) with $40 \mu \mathrm{l}$ of a $1 \times 10^{8} \mathrm{P}$. syringae cells $/ \mathrm{ml}$ culture (adjusted with sterile distilled $\mathrm{H}_{2} \mathrm{O}$ to $\mathrm{OD} 600=0.24$ ). After 2, 4,7 , and 9 days, the necrotic zone around the inoculation site was imaged. Every treatment was repeated at least 6 times and on at least three different plants. A separate round of experiments was used to quantify $P$. syringae growth in the agroinfiltrated leaves. Ten $\mu$ l of a $P$. syringae cell suspension $(\mathrm{OD} 600=0.24)$ was applied to needle-pricked leaves. Plants were covered with clear polyethylene bags and sealed around the base using elastic bands, to keep humidity. After 1, 3, and 6 days, six leaf discs $(0.8 \mathrm{~cm}$ diameter) per treatment were excised from inoculated areas, pooled and ground (Ultra-Turrax T25 basic, IKA Labortechnik, Germany) in $10 \mathrm{mM} \mathrm{MgSO}_{4}(1 \mathrm{ml} /$ disc), by keeping the tube in an ice bath. An aliquot of the homogenate was plated on LB-rifampicin agar at three different dilutions $\left(10^{-3}, 10^{-4}\right.$, and $10^{-5}$ ) and colonies were counted 1 and 2 days after incubation at $28^{\circ} \mathrm{C}$. Another aliquot $(15 \mu \mathrm{l})$ of the homogenate was mixed with $110 \mu \mathrm{l}$ of LB-rifampicin and incubated in 96-well microtiter plates at $28^{\circ} \mathrm{C}(120 \mathrm{rpm}$ for $16 \mathrm{~h})$. Optical density at $550 \mathrm{~nm}$ was then measured with a Bio-Rad microplate reader (BioRad, Richmond, CA, United States). P. syringae inoculation was independently repeated on at least six leaves of at least three different plants.

For $B$. cinerea and A. alternata infections, upper leaves of systemically transformed $N$. benthamiana plants (11 days after A. tumefaciens toothpick inoculation) were challenged with 10 $\mu \mathrm{l}$ of germination solution (20 mM glucose, $20 \mathrm{mM}$ potassium phosphate) containing $10^{5}$ or $10^{7}$ conidia/ml of $B$. cinerea or A. alternata, respectively. All plants were covered with transparent polyethylene bags and sealed around the base using elastic bands, to keep humidity. The appearance of necrotic spots was assessed 2, 4, and 6 days after inoculation and disease incidence recorded.

Each pathogen-PVX construct combination was assayed on at least four different leaves of at least three different plants. All infection assays were repeated at least twice. Data are presented as mean values \pm SD of different experiments. To assess statistical differences between control (PVX::gfp) and PI expressing samples a Yates' corrected chi-squared test (twosided) was used. Statistical differences between treatments at each time point were assessed by one-way ANOVA with post hoc Tukey HSD Tests.

\section{RT-PCR Analysis of Pls Expression}

For RT-PCR validation of transient PI expression, total RNA was isolated from $100 \mathrm{mg}$ of control (PVX:::gfp) and PIs transformed $N$. benthamiana leaves ( 5 days post agroinfiltration) using the TRI Reagent (Ambion). RT-PCR was performed on equal amounts of total RNA using the Reverse Transcription System kit (Promega) and of $1 \mu \mathrm{g}$ random primers for each $2 \mu \mathrm{g}$ total RNA, following the supplier's instructions. Two microliters of first-strand cDNA solution were used as a template for RT-PCR experiments. Amplifications of Pin1, PKPI, and $\beta$-tubulin gene transcripts were performed as indicated earlier (Turrà et al., 2009). Plasmid DNA of the cloned cDNAs PPI3B2 and PKI1 (Turrà et al., 2009) were used as positive controls and PCR products of the constitutively expressed $\beta$-tubulin gene used as a quantitative control. Amplifications were repeated in independent occasions on neo-synthesized cDNA from at least three independently repeated experiments.

\section{Protein Extractions}

For the extraction of the TSP, ten grams of untransformed or of locally transformed $N$. benthamiana leaf areas (7 days after A. tumefaciens syringe-inoculation) were ground with an UltraTurrax Homogenizer in $30 \mathrm{ml}$ of $0.1 \mathrm{M}$ sodium phosphate buffer (pH 6.8) by keeping the tube in an ice bath. The slurry was incubated $1 \mathrm{~h}$ on ice under occasional shaking, filtered through four layers of cheesecloth, and cleared by centrifugation at 50,000 $\mathrm{g}$ for $1 \mathrm{~h}$ at $4^{\circ} \mathrm{C}$ in a Beckman L7-65 Ultracentrifuge (Beckman, Milan, Italy).

Apoplastic fluids (AF) were prepared from $N$. benthamiana leaves according to the method of Moehnke et al. (2008), with minor modifications. Briefly, $10 \mathrm{~g}$ of leaf material was vacuuminfiltrated for 2 min with $100 \mathrm{ml}$ infiltration buffer [100 mM Tris/ $\mathrm{HCl}$ (pH 7.5), $10 \mathrm{mM} \mathrm{MgCl}_{2}$ ]. Leaves were then dried with sterile paper towels and placed into the barrel of a $50 \mathrm{ml}$ syringe. The syringe was subsequently inserted into a $50 \mathrm{ml}$ falcon tube with the needle hub facing downwards and spun at 2,000 g for $10 \mathrm{~min}$ at $4^{\circ} \mathrm{C}$. After centrifugation, AF was collected from the bottom of the centrifuge tube.

All protein extracts were subjected to filtration and dialysis by using Centriprep YM-3 devices (Amicon Corporation, Danvers, MA, United States), filter sterilized $(0.22 \mu \mathrm{m})$ and stored at $-20^{\circ} \mathrm{C}$ if not immediately used. Protein concentrations were determined by a Bradford DC protein assay (Bio-Rad) using bovine serum albumin as a standard.

\section{In vitro Evaluation of Plant Crude Extracts Activity}

Inhibition assays of $N$. benthamiana TSP and AF proteolytic activities by TSP extracted from PVX::gfp, PVX::PKI2, and PVX::PPI2C4 transformed $N$. benthamiana leaf areas were 
carried out in microtiter plates by using azocasein (SigmaAldrich) as chromogenic substrate and in-gel protease assays using the Bio-Rad zymogram buffer system, following the previously described procedures (Tian et al., 2004; Hermosa et al., 2006). For the first method, a total of $20 \mu \mathrm{g}$ of TSP and $\mathrm{AF}$ from untransformed plants were preincubated with $20 \mu \mathrm{g}$ of TSP from PVX-transformed plants in a volume of $250 \mu \mathrm{l}$ for $30 \mathrm{~min}$ at room temperature, and followed by incubation with $200 \mu \mathrm{l}$ of $1 \%$ azocasein $(\mathrm{w} / \mathrm{v})$ at $37^{\circ} \mathrm{C}$ for $1 \mathrm{~h}$. The reaction was halted by adding an equal volume of $10 \%(\mathrm{w} / \mathrm{v})$ TCA. After $10 \mathrm{~min}$ on ice, the reaction mixture was centrifuged for $10 \mathrm{~min}$ at $13,000 \mathrm{~g}$ and the supernatant mixed with an equal volume of $1 \mathrm{M} \mathrm{NaOH}$. The optical density at $450 \mathrm{~nm}$ was then determined with a Bio-Rad microplate reader. The percentage of the remaining protease activity was therefore plotted relative to that of TSP and AF samples from untransformed plants incubated with TSP extracted from PVX: $g f p$ transformed plants. Experiments were performed in triplicate and repeated in at least two independent occasions. Data represent the mean value $[ \pm S D$ (standard deviation)] across all experiments. Statistical differences between treatments were assessed by one-way ANOVA with post hoc Tukey HSD Tests.

For zymogen in-gel protease assays, $20 \mu \mathrm{g}$ of TSP from mock- $\left(\mathrm{H}_{2} \mathrm{O}\right)$ and PVX-infiltrated $N$. benthamiana leaf areas were mixed with zymogram sample buffer and loaded on a $10 \%$ SDS-polyacrylamide gel without boiling or addition of reducing reagents. Following electrophoresis, the gel was incubated in $1 \mathrm{x}$ zymogram renaturation buffer for $30 \mathrm{~min}$. Then the gel was incubated in $1 \mathrm{x}$ zymogram development buffer for $18 \mathrm{~h}$ at $37^{\circ} \mathrm{C}$ before staining with $0.5 \%$ Coomassie Brilliant Blue. Areas of protease activity were revealed as cleared bands on a blue background.

To assess the antifungal activity of plant crude extracts, 10 $\mu \mathrm{l}$ of a solution of $10^{7} \mathrm{conidia} / \mathrm{ml}$ of $B$. cinerea or A. alternata were mixed with $40 \mu \mathrm{l}$ of plant crude extracts $(50 \mu \mathrm{g} / \mathrm{ml})$ and 40 $\mu \mathrm{l}$ of Potato Dextrose Broth (PDB). After $48 \mathrm{~h}$ of incubation at $28^{\circ} \mathrm{C}$ in a 96 -well microtiter plate, the change in optical density at $550 \mathrm{~nm}$ was determined using a Bio-Rad microplate reader. Each experiment was repeated at least three times and data presented as the percentage of growth inhibition relative to that of the PVX: $g f p$ transformed plants. Data correspond to mean values $( \pm \mathrm{SD})$ across all experiments. Statistical differences between treatments were assessed by one-way ANOVA with post hoc Tukey HSD Tests.

\section{Determination of Plant Growth and Analysis of Leaf Surface Expansion}

The effect of PI transient expression on $N$. benthamiana shoot and root growth was evaluated in pot experiments. Seedlings were grown in vitro at $23^{\circ} \mathrm{C}$ under $24 \mathrm{~h}$ fluorescent lighting (3,500-6,000 lux) on Murashige and Skoog (MS) salt medium (ICN Pharmaceuticals Inc., Cleveland, $\mathrm{OH}$, United States), and 1\% bacto-agar (Difco, Detroit, MI, United States) first and then transferred to soil in $10 \mathrm{~cm}$ diameter pots and left to grow in a phytocabinet as described above. Plantlets at the fourth-leaf stage were A. tumefaciens toothpick inoculated, as described above. Complete shoots and roots were collected separately (21 days after agroinfection). Roots were briefly rinsed to remove attached sand, quickly dried with a paper towel, incubated for $72 \mathrm{~h}$ at $75^{\circ} \mathrm{C}$ and weighted to estimate the dry weight. Experiments were repeated twice $(n=10)$. Data correspond to mean values ( \pm SD) across all experiments. Statistical differences between treatments were assessed by one-way ANOVA with post hoc Tukey HSD Tests.

To determine leaf disc surface expansion and leaf strip curvature of PI transformed leaf areas, the methods were adapted from those of Gevaudant and coworkers (Gevaudant et al., 2007). Briefly, fully developed PVX-transformed N. benthamiana leaf areas (7 days after $A$. tumefaciens syringe-inoculation) were used. Leaf discs $(1 \mathrm{~cm}$ diameter $)$ and strips $(2 \times 10 \mathrm{~mm})$ were cut from the interveinal region and incubated for $24 \mathrm{~h}$ at room temperature in $10 \mathrm{mM}$ Sucrose, $10 \mathrm{mM} \mathrm{KCl}$, and $0.5 \mathrm{mM}$ 2-(N-Morpholino)ethanesulfonic acid hemisodium salt (MES), $\mathrm{pH}$ 6.0. Leaf discs were photographed with a digital camera before and after the treatment and their surface estimated as their pixel content, by the use of the ImageJ software (Collins, 2007). Differences in surface increase between treatments and controls (PVX::gfp) were expressed as a percentage of the initial disc area. Leaf strip curvature was estimated as the angle made by the two tangents to the two terminal parts of each strip. Each experiment was repeated three times on at least 15 leaf discs or strips per treatment. Statistical differences between treatments were assessed by one-way ANOVA with post hoc Tukey HSD Tests.

For microscopic analysis of cell size and nuclei density, adaxial epidermis from agroinfiltrated $(7,13$, and 20 days after A. tumefaciens syringe-infiltration) $N$. benthamiana leaf areas was used. Briefly, entire leaves were detached and immersed for $1 \mathrm{~h}$ in $1 \%(\mathrm{v} / \mathrm{v})$ Tween 20 before peeling off the adaxial epidermis from the agro-infiltrated area. Tissues were mounted in water and observed with an Axioskop2 Plus microscope (Zeiss, Milan, Italy). Cell size measurement was performed by using the ImageJ software (Collins, 2007). For nuclear visualization, leaf epidermis was stained with 4',6-diamidino-2-phenylindole (DAPI; 1 $\mu \mathrm{g} / \mathrm{ml}$ ) for $20 \mathrm{~min}$, and mounted in $50 \%$ (v/v) phosphatebuffered saline (PBS)-glycerol for observation. Quantification of epidermial cell size and nuclear density was repeated at least four times on 500 cells/leaf per treatment. To assess statistical differences between control (PVX and PVX: $g f p$ ) and PI expressing samples a Yates' corrected chi-squared test (two-sided) was used.

\section{Sequence Data and Bioinformatic Analysis}

BLAST searches were performed in the NCBI database ${ }^{1}$. Signal peptide and extracellular localization predictions were performed by using the SignalP and WoLF PSORT softwares, respectively (Emanuelsson et al., 2007; Horton et al., 2007).

\footnotetext{
${ }^{1}$ http://www.ncbi.nlm.nih.gov
} 
Sequence data from this article can be found in the GenBank data library under accession numbers DQ087220 (PKI1), JX878493 (PKI2), DQ087224 (PPI3A2), DQ087221 (PPI3B2), DQ087223 (PPI2C4).

\section{RESULTS}

\section{Potato Kunitz and Pin1 PIs Are Efficiently Expressed in Nicotiana benthamiana Plants}

Five PCR fragments corresponding to three previously characterized (PPI3A2, PPI3B2, and PPI2C4) full-length Pin1 cDNAs and two full-length Kunitz cDNAs, one of them previously characterized (PKI1) and a novel one (PKI2) were amplified from potato sprouts (Turrà et al., 2009). BlastX analysis of the latter gene indicated about 95\% identity with the S. tuberosum P1H5 gene (AAM10743) and 94\% identity with PKI1. All amplified PIs were predicted to be secreted to the apoplast according to the SignalP and WoLF PSORT prediction tools.

Recombinant PVX plasmids containing the full-length cDNA of all of the above mentioned PI genes were used for transient transformation of $N$. benthamiana plants. For local expression of PI genes, the method of transient Agrobacterium-mediated expression by leaf infiltration was chosen. Transgene expression in agroinfiltrated leaf patches was confirmed 5 days after agroinfiltration by extracting total RNA and performing RT-PCR using PI specific oligonucleotides (Supplementary Table S1) followed by DNA sequence analysis (Figures 1A,B). For systemic transgene expression, a toothpick-inoculation system was used. In this case transgene expression in the upper non-inoculated parts of the plant was verified by monitoring GFP fluorescence 5, 7, 11, 14, and 21 DPI with the PVX::gfp viral construct. All inoculated plants displayed systemic GFP expression starting from 11 DPI (Figure 1C).

\section{Transient Expression of Kunitz and Pin1 Inhibitor Genes Increases Plant Resistance Toward the Fungal Pathogens Botrytis cinerea and Alternaria alternata}

To evaluate the effect of Kunitz and Pin1 expression on plant resistance toward fungal pathogens, plants systemically transformed with PVX::gfp and PVX::PIs were challengeinoculated with suspensions of $B$. cinerea and A. alternata spores. Necrotic symptoms 6 days postinoculation are shown in Figures 2A, 3A. The size of the disease lesions was also measured after 2, 4, and 6 days in the case of $B$. cinerea and after 4 and 6 days in the case of A. alternata infection (Figures 2B, 3B).

While $B$. cinera symptoms developed markedly on PVX::PPI3A2 transformed plants, those expressing the PKI1 or PKI2, PPI3B2, and PPI2C4 genes exhibited partial or almost complete disease resistance, respectively (Figure 2A). Noteworthy, the reduction in the severity of necrotic lesions ranged from $87 \%$ (PVX::PKI2) to 100\% (PVX::PPI3B2) 6 days after spore inoculation when compared to the control (PVX::gfp) treated plants (Figure 2B).
A

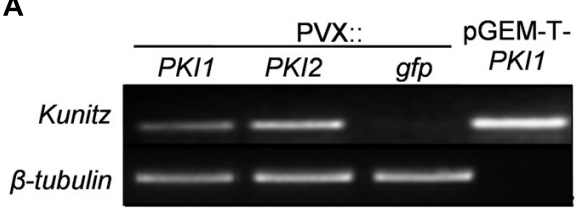

B

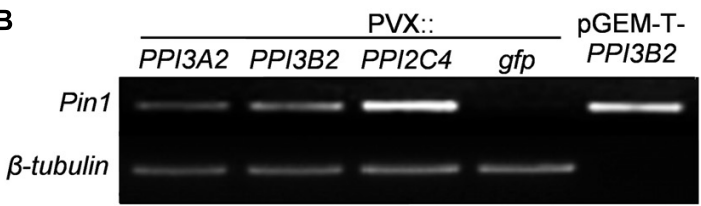

C

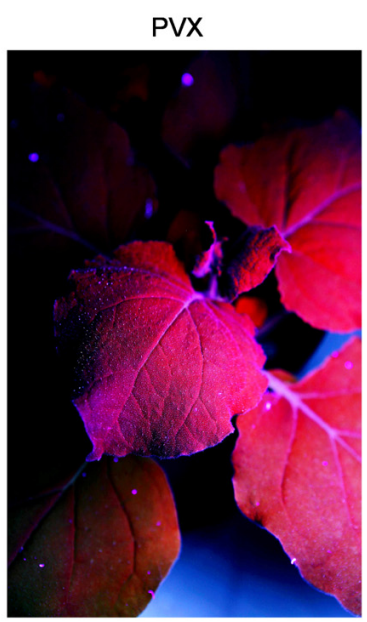

PVX::gfp

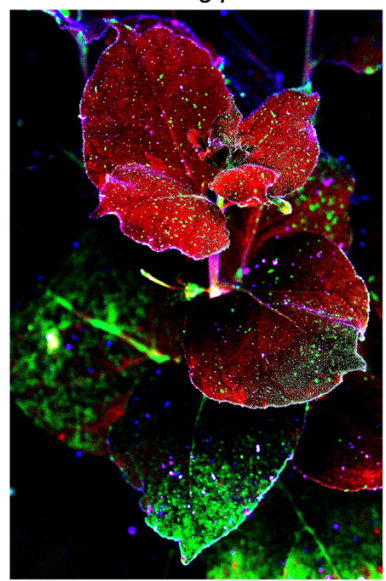

FIGURE 1 | Functional validation of PVX-mediated gene expression. (A,B) RT-PCR analysis of potato PKPI and Pin1 expression in control (PVX::gfp) and in PKI1, PKI2 (A) or PPI3A2, PPI3B2, PPI2C4 (B) transiently expressing Nicotiana benthamiana plants. Total RNA was extracted from N. benthamiana leaves 5 days after Agrobacterium tumefaciens infiltration and subjected to RT-PCR analysis. Plasmids pGEM-T-PKI1 (A) and pGEM-T-PPI3B2 (B) were used as positive amplification controls. The $\beta$-tubulin gene was used to confirm an equal amount of total RNA among samples. Each sample consisted of leaf tissues pooled from at least four independently transformed plants. Representative results from three independent experiments are shown. (C) Systemic transgene expression was validated by analyzing GFP fluorescence in newly formed $N$. benthamiana leaves at different time intervals 11 days after toothpick inoculation of basal leaves with a colony of A. tumefaciens carrying either the pGR106 (PVX control) or the pGR106-gfp (PVX::gfp) plasmid. Photographs in (C) are representatives of UV-irradiated N. benthamiana plants $11 \mathrm{dpi}$. 


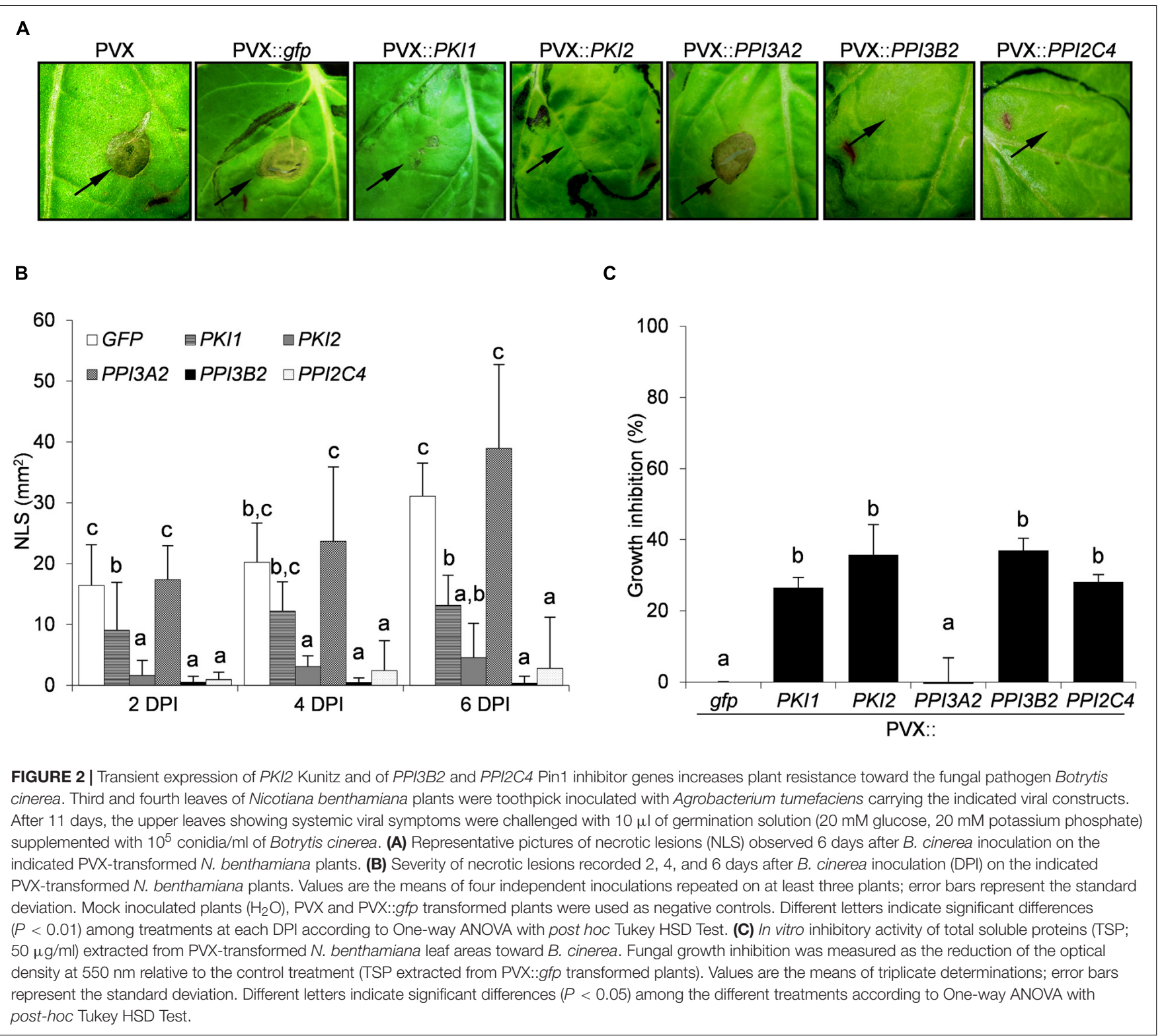

Differently from $B$. cinerea infection, no symptoms developed on any of the A. alternata challenged leaves 2 days postinfection (data not shown). Marked necrotic areas started to appear 4 days post-infection on PVX::PPI3B2, PVX::PPI2C4, and PVX::gfp transformed plants, while those expressing PKI2, PKI1, and PPI3A2 genes exhibited a significant increase of disease resistance (PVX::PKI1, 84\%; PVX::PKI2, 93\%; PVX::PPI3A2, 68\%). Six days post-infection all PI expressing plants showed significantly increased resistance (varying between 50 and 66\%) when compared to the control ones (PVX::gfp) (Figure 3B).

To understand if the inhibition of $B$. cinerea and A. alternata growth on PI-expressing $N$. benthamiana plants depended on the chemical composition of leaf TSP, the in vitro inhibitory activity of TSP extracted from PIs-transformed $N$. benthamiana leaf areas was compared to that of PVX:: $g f p$ transformed ones. Data reported in Figures 2C, 3C show that all TSP extracted from PItransformed plants were able to reduce the growth of both fungal pathogens, except those from PPI3A2-expressing plants that selectively inhibited $A$. alternata but not $B$. cinerea proliferation.

\section{Transient Expression of PKI2, PPI3A2, and PPI2C4 PI Genes Increases Plant Resistance Toward the Bacterial Pathogen Pseudomonas syringae pv. tabaci}

To determine whether Kunitz and Pin1 gene overexpression confers protection against bacterial phytopathogens in $N$. benthamiana plants, a cell suspension of $P$. syringae pv. tabaci was syringe-infiltrated into the abaxial side of PVX::PIs or PVX::gfp transformed leaf areas. Chlorotic and 
A

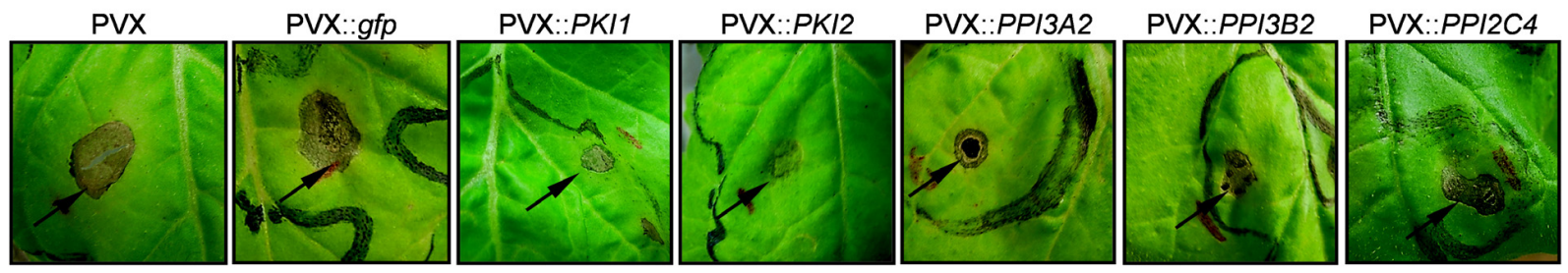

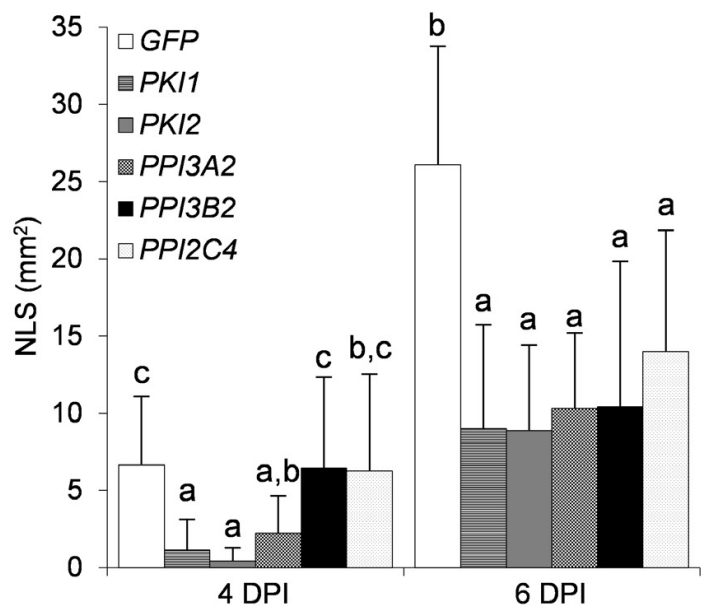

C

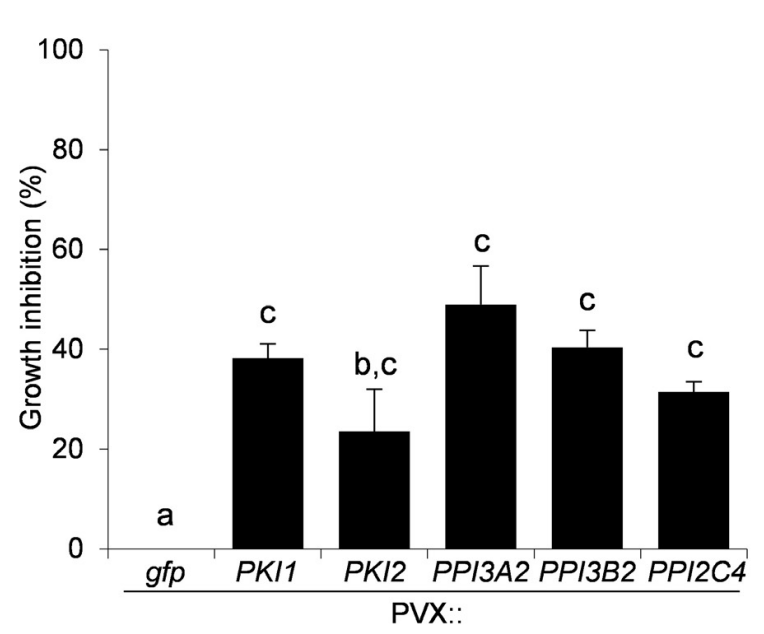

FIGURE 3 | Transient expression of several Kunitz and Pin1 genes increases plant resistance toward the fungal pathogen Alternaria alternata. Third and fourth leaves of Nicotiana benthamiana plants were toothpick inoculated with Agrobacterium tumefaciens carrying the indicated viral constructs. After 11 days, the upper leaves showing systemic viral symptoms were challenged with $10 \mu \mathrm{l}$ of germination solution ( $20 \mathrm{mM}$ glucose, $20 \mathrm{mM}$ potassium phosphate) supplemented with $10^{7}$ spores/ml of $A$. alternata. (A) Representative pictures of necrotic lesions (NLS) observed 6 days after $A$. alternata inoculation (DPI) on the indicated PVX-transformed $N$. benthamiana plants. (B) Severity of necrotic lesions recorded 4 and 6 days after $A$. alternata infection on the indicated PVX-transformed $N$. benthamiana plants. Values are the means of four independent inoculations repeated on at least three plants; error bars represent the standard deviation. Mock inoculated plants $\left(\mathrm{H}_{2} \mathrm{O}\right)$, PVX and PVX::gfp transformed plants were used as negative controls. Different letters indicate significant differences $(P<0.01)$ among treatments at each DPI according to One-way ANOVA with post-hoc Tukey HSD Test. (C) In vitro inhibitory activity of total soluble proteins (TSP) extracted from PVX-transformed $N$. benthamiana leaf areas toward $A$. alternata. Fungal growth inhibition was measured as the reduction of the optical density at $550 \mathrm{~nm}$ relative to the control treatment (TSP extracted from PVX::gfp transformed plants). Values are the means of triplicate determinations; error bars represent the standard deviation. Different letters indicate significant differences $(P<0.05)$ among the different treatments according to One-way ANOVA with post-hoc Tukey HSD Test.

necrotic symptoms markedly developed on PVX::gfp and PVX::PKI1 transformed plants 7 days post-infection (Figure 4A). Interestingly, while a mild reduction of symptoms was observed on PVX::PPI3A2- and PVX::PPI3B2-infected plants, in those expressing the PKI2 or the PPI2C4 gene only a small necrosis surrounding the point of inoculation, comparable to that observed in the water inoculated leaves (data not shown), was visible (Figure 4A).

As necrotic lesions showed an irregular outline and it was difficult to exactly determine the area of necrosis, the number of surviving $P$. syringae cells in infected leaves was quantified (Figures 4B,C). Leaf discs were collected from distinct infiltrated areas from each treated plant, homogenized and plated on LB-rifampicin agar at three different dilutions $\left(10^{-3}, 10^{-4}\right.$, and $10^{-5}$ ). Alternatively, a $10^{-3}$ dilution was mixed with LB-rifampicin in 96 well-plates and incubated with constant shaking at $28^{\circ} \mathrm{C}$ for $16 \mathrm{~h}$. Colony counting and optical density readings retrieved similar results, reported in Figures 4B,C.
No inhibition of bacterial growth was observed 6 days after inoculation in PVX::PKI1-transformed plants when compared to control ones (PVX:: $g f p$ ). Strikingly, a strong reduction of $P$. syringae population was detected in plants transformed with the PVX::PPI3B2 and PVX::PPI3A2 vectors ( $40-60 \%)$, and complete resistance was observed in those transformed with the PKI2 and PPI2C4 genes. As expected, mock infiltrated leaves showed no necrotic symptoms and no bacterial colonies grew after plating their homogenates.

\section{Transient Expression of PPI2C4 and PKI2 Genes Alters Plant Development}

PVX::PKI2 and PVX::PPI2C4 transiently transformed $N$. benthamiana plants showed, in contrast to the untransformed and PVX::gfp transformed plants, several developmental abnormalities. Hypertrophy and unusual accumulation of trichomes were observed in locally transformed leaf areas 
$\mathbf{A}$

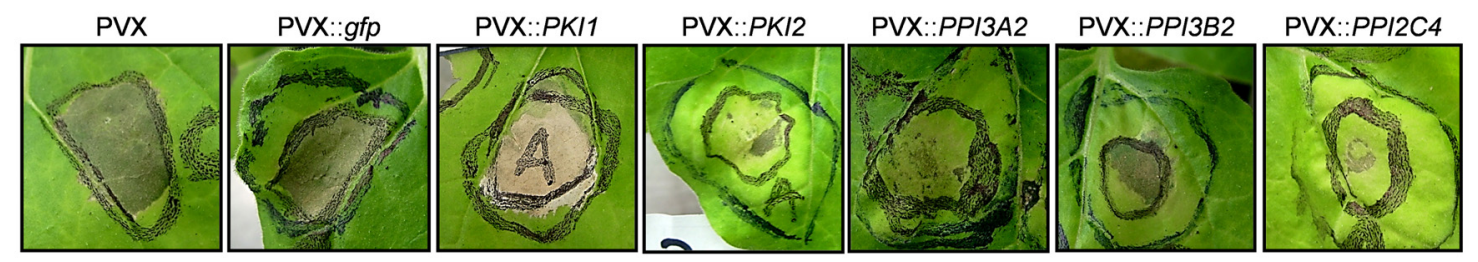

B

C

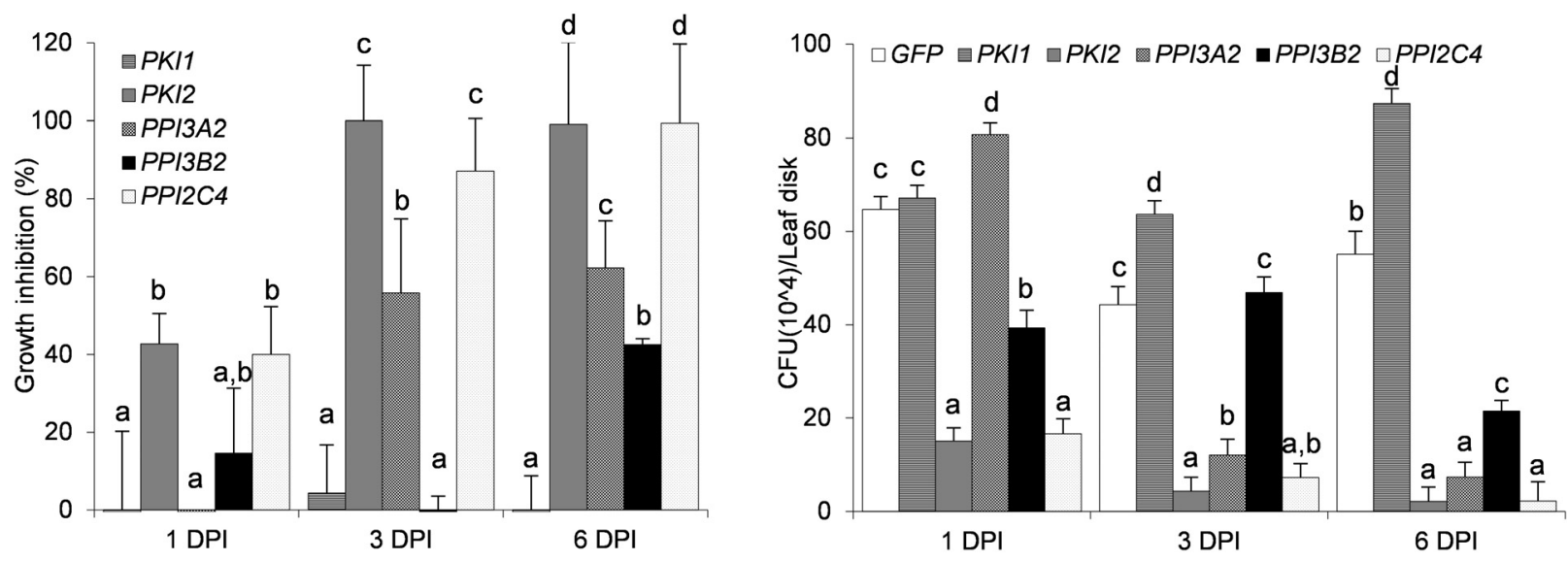

FIGURE 4 | Transient expression of PKI2 Kunitz inhibitor and of PPI3A2 and PPI2C4 Pin1 inhibitor genes increases plant resistance toward the bacterial pathogen Pseudomonas syringae pv. tabaci. Fully developed leaves of Nicotiana benthamiana plants were syringe-infiltrated with a solution of Agrobacterium tumefaciens carrying the indicated viral constructs. After 5 days, the previously transformed leaf areas were challenge infiltrated with $40 \mu l$ of a $1 \times 10^{8} P$. syringae pv. tabaci cells/ml culture (A) or needle-pricked and $10 \mu \mathrm{l}$ of the same $P$. syringae cell suspension were applied at the center of the wounded area (B,C). (A) Representative pictures of chlorotic and necrotic symptoms observed 7 days after $P$. syringae pv. tabaci infiltration. (B,C) The number of surviving bacterias 1 , 3, and 6 days after leaf infection with $P$. syringae was determined. Leaf disks $\left(0.8 \mathrm{~cm}\right.$ diameter) were excised from the inoculated areas, ground in $10 \mathrm{mM} \mathrm{MgSO}_{4}$ and homogenates were either serially diluted, plated and colonies counted on LB-rifampicin agar (C) or mixed with the LB-rifampicin and optical density (OD) at 550 nm determined after $16 \mathrm{~h}$ of incubation $\mathbf{( B )}(P<0.001)$. $P$. syringae growth inhibition in $\mathbf{( B )}$ is expressed in percentage as the reduction in OD of the $P V X:: P /$ treated samples compared to the control ones (PVX::gfp). In all cases values are the means of four independent inoculations repeated on at least three different plants; error bars represent the standard deviation. Mock inoculated plants $\left(\mathrm{H}_{2} \mathrm{O}\right), \mathrm{PVX}$ and PVX::gfp transformed plants were used as negative controls. Different letters indicate significant differences $(P<0.01)$ among the different treatments according to One-way ANOVA with post hoc Tukey HSD Test.

21 days after syringe-infiltration (Figures 5A-C). Because these macroscopic phenotypes are indicative of a role of PKI2 and PPI2C4 serine PIs in the regulation of cell division and plant development, we tested whether locally transformed $N$. benthamiana leaves showed higher rates of cell expansion. Interestingly, leaf discs from PVX::PKI2 and PVX::PPI2C4 transformed plants expanded twice as much as the control ones (PVX:: $g f p$ ) in a $24 \mathrm{~h}$ incubation period (Figure 5D). In an additional set of experiments, leaf strip curvature or epinasty, a phenotype often related to cell expansion (Keller and Van Volkenburgh, 1997), was analyzed by measuring the curvature of leaf strips excised from PVX-transformed patches $24 \mathrm{~h}$ after incubation. Notably, PPI2C4- and PKI2-expressing leaf strips bent 3-4-fold more than GFP-expressing ones (Figure 5E), indicating leaf asymmetrical expansion, with the adaxial surface growing faster than the abaxial one.

To confirm the relevance of PKI2 and PPI2C4 proteins in the regulation of plant development, $N$. benthamiana seedlings were systemically transformed with the PVX::PKI2 and PVX::PPI2C4 viral constructs. Morphological analyses showed that PKI2- and PPI2C4-overexpressing plants grew faster, developed bigger root systems and leaves and exhibited an increase in root and shoot dry weight of more than three and two times, respectively, when compared to controls (Figures $5 \mathbf{F}-\mathbf{J}$ ).

\section{Effects of PI Expression on Nicotiana benthamiana Endogenous Protease Activity, Epidermal Cell Expansion, and Division}

To ask whether the hypertrophic phenotype observed in PKI2 and PPI2C4 expressing leaves reflects induction of cell division, we performed a detailed microscopic analysis of the adaxial epidermis of PVX::PPI2C4 and PVX::gfp agroinfiltrated patches 7,13 , and 21 DPI. While no alterations of cell morphology could be observed, an increase in the average cell size before (7 DPI) and in nuclear density after (13 DPI) was detected in PPI2C4 expressing plants (Figures 6A-C,F). Accordingly, PPI2C4 expression also lead to the appearance of tight clusters of small-sized cells, some of which being trichomes (Figures 6D,E), 13 DPI. Similar results were obtained in PVX::PKI2 expressing leaves (data not shown). As expected, none of these changes 

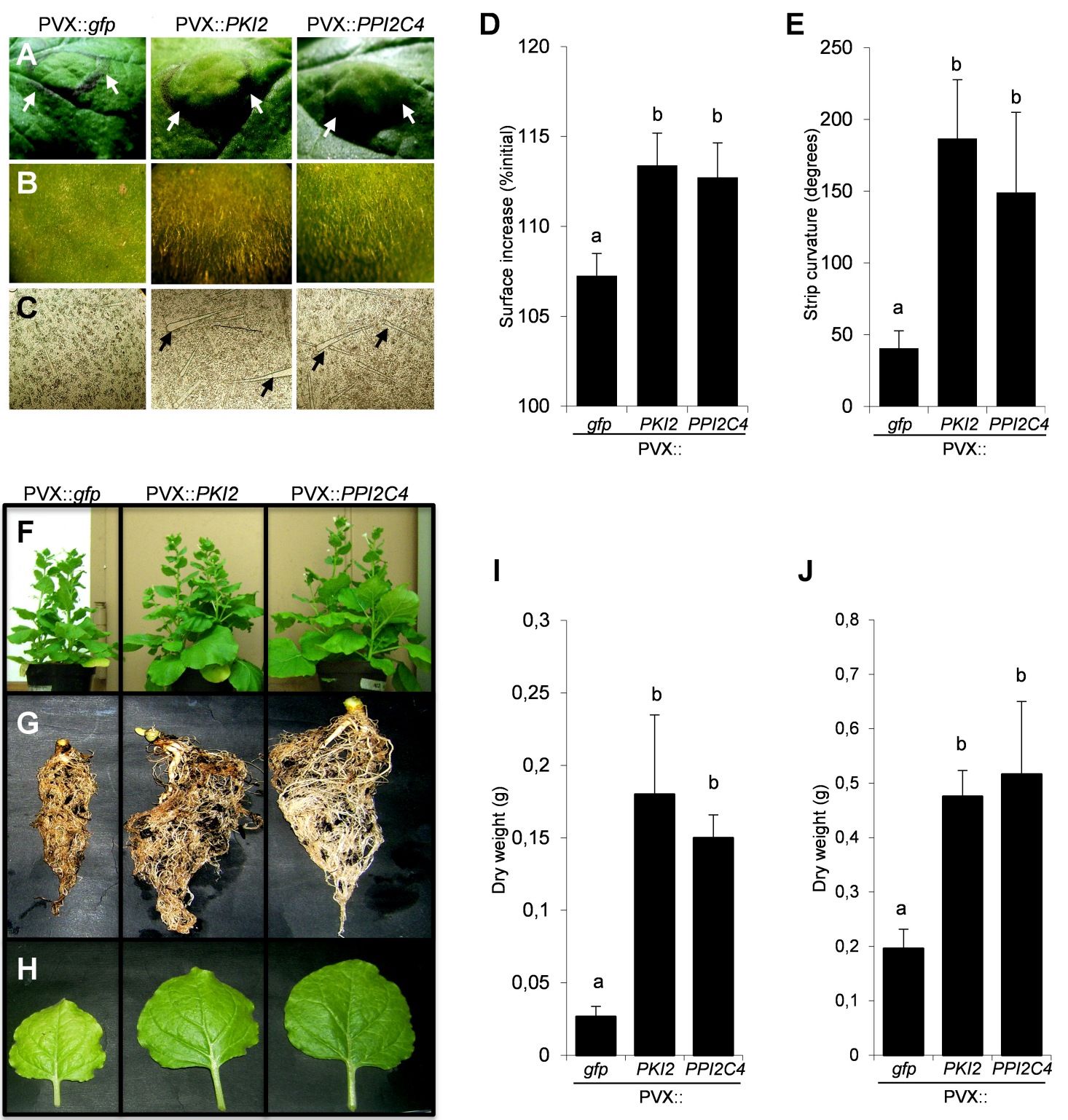

FIGURE 5 | Transient expression of PKI2 and PPI2C4 genes enhances plant growth and trichome accumulation. (A,B) Representative pictures of Nicotiana benthamiana transformed leaf areas 21 days after syringe-infiltration with a solution of Agrobacterium tumefaciens carrying the indicated viral constructs. Note the leaf area enlargement (A) and overaccumulation of trichomes (B) in PVX::PKI2 and PVX::PP12C4 transformed leaves. (C) Stereomicroscopic view (40X) of adaxial leaf epidermal cells shows higher number and bigger size of trichomes in PVX::PKI2 and PVX::PPI2C4 transformed leaf areas. (D,E) Curvature of leaf strips and area increase of leaf discs. Leaf strips and discs $(1 \times 1 \mathrm{~cm})$ from transiently transformed leaf areas (7 days after $A$. tumefaciens syringe-infiltration) were incubated for $24 \mathrm{~h}$ as indicated in section "Materials and Methods". Images were taken before and after incubation and the strip curvature (E) and the increase of leaf disc area (D) (expressed as a percentage of the initial leaf disc area) were calculated. Values are the means of 15 different leaf strips or discs measurements repeated in three independent experiments; error bars represent the standard deviation. Different letters indicate significant differences $(P<0.01)$ according to One-way ANOVA with post hoc Tukey HSD Test. (F-J) Effects of systemic PKI2 and PPI2C4 over-expression on plant growth. Third and fourth leaves of 2-3-week-old N. benthamiana seedlings were tooth-pick incoculated with the indicated viral constructs. PVX or PVX::gfp transformed plants were used as controls. Representative pictures of entire plants (F), root systems (G) and newly formed leaves $\mathbf{( H )}$, and measurement of root $\mathbf{(} \mathbf{I})$ and shoot $(\mathbf{J})$ dry weight 21 days after $A$. tumefaciens inoculation. Values are the means of 10 different measurements repeated in three independent experiments; error bars represent the standard deviation. Different letters indicate significant differences $(P<0.01)$ according to One-way ANOVA with post hoc Tukey HSD Test.

was observed in control PVX (data not shown) or PVX::gfp transformed leaves.

To understand if misregulation of cell division in these plants was associated with an alteration of the endogenous protease activity, TSP from mock- $\left(\mathrm{H}_{2} \mathrm{O}\right)$ and PVX-infiltrated $N$. benthamiana leaf areas were either directly used in a in-gel protease assay (Figure 7A) or the first extracts mixed with the latter's to measure the residual protease activity 

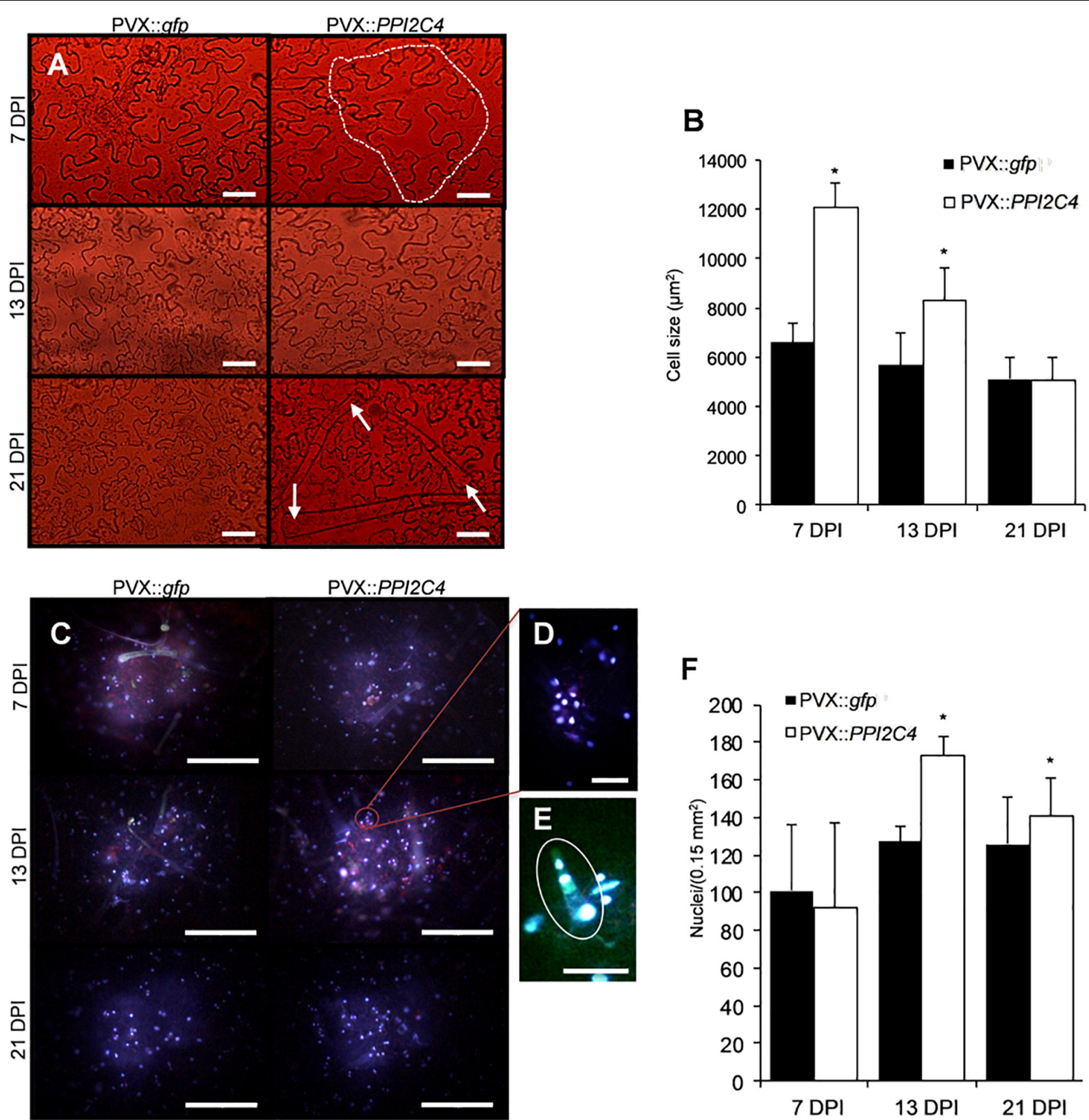

FIGURE 6 | Effect of PPI2C4 gene overexpression on epidermal cell division and trichome accumulation. (A,C,D,E) Representative pictures of Nicotiana benthamiana transformed epidermal cells under light microscopy (A) or fluorescence microcopy (DAPI staining) (C-E), 7, 13 and 21 days after syringe-infiltration (DPI) with a solution of Agrobacterium tumefaciens carring the indicated viral constructs. (D) Magnification of (C) to show details of clustered nuclei. (E) Magnification of a neoforming trichome observed 13 DPI in PVX::PPI2C4 transformed leaves. Note the bigger size of epidermal cells 7 DPI (circled) and number of trichomes 21 DPI (pointed with arrowheads) in PVX:: PPI2C4 transformed leaves. Scale bar, $10 \mu \mathrm{m}$ in (A,D,E) and $50 \mu \mathrm{m}$ in (C). (B,F) Cell size (B) and number of nuclei (F) in transformed adaxial leaf epidemis $\left(n=500\right.$ cells, in at least four leaves) 7,13 , and 21 DPI ( ${ }^{*} P<0.0001$ versus PVX::gfp according to Yates' corrected chi-squared test).

(Figure 7B). Similar results were obtained in these two assays. In the first case, an additional protease band was clearly visible in the GFP-expressing sample and in the mockinoculated control, but not in the TSP from PVX::PKI2 and PVX::PPI2C4 transformed plants (Figure 7A). In the second case, TSP from PKI2- and PPI2C4-expressing samples showed
100 and $60 \%$ higher inhibitory activities, respectively, than those from control plants (GFP expressing). Interestingly, TSP from PKI2- and PPI2C4-expressing samples also showed a high degree of inhibition (90\%) toward $N$. benthamiana apoplastic protease activity, when compared to the GFPexpressing controls (Figure 7C). 
A

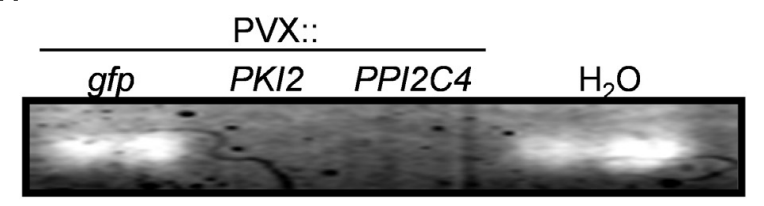

B

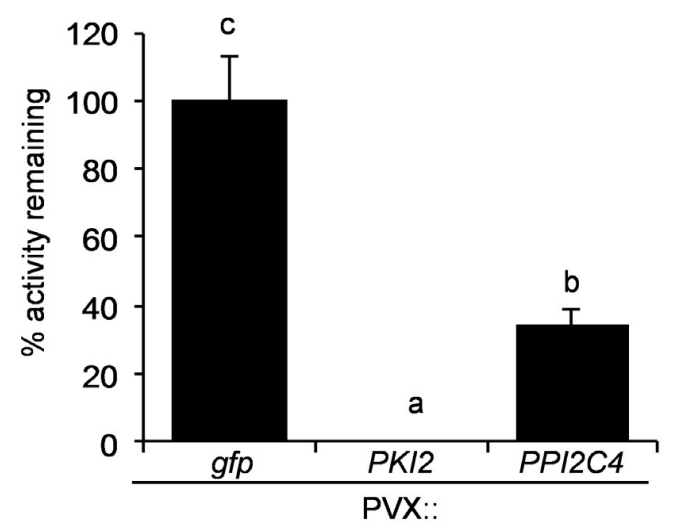

C

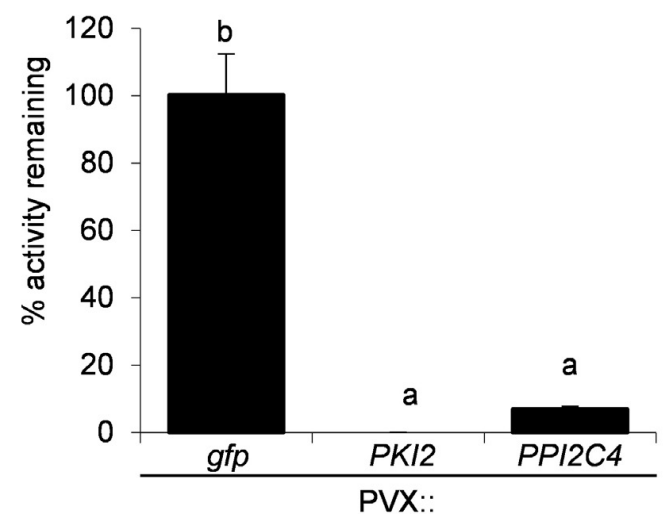

FIGURE 7 |PKI2 and PPI2C4 inhibit Nicotiana benthamiana apoplastic proteasic activity. (A) Zymogen in-gel protease assays of total soluble proteins (TSP) extracted from mock- $\left(\mathrm{H}_{2} \mathrm{O}\right)$ and $\mathrm{PVX}$-infiltrated Nicotiana benthamiana leaf areas (7 days after syringe-infiltration). (B,C) TSP (B) or intercellular fluids (C) isolated from untransformed $N$. benthamiana plant leaves were incubated with TSP extracted from PVX-transformed $N$. benthamiana leaf areas (7 days after syringe-infiltration) and the remaining protease activity was analyzed by measuring the change in optical density at $450 \mathrm{~nm}$ after $1 \mathrm{~h}$ of incubation in the presence of a $1 \%(\mathrm{w} / \mathrm{v})$ azocasein solution. Values are the means of triplicate determinations; error bars represent the standard deviation. Different letters indicate significant differences $(P<0.05)$ according to One-way ANOVA with post hoc Tukey HSD Test.

\section{DISCUSSION}

Hydrolysis and protein synthesis, as well as the regulation of these physiological processes, are fundamental phenomena impacting both plant development and susceptibility/resistance to pathogens (Rawlings et al., 2004, 2014; Turrà and Lorito, 2011; Grosse-Holz and van der Hoorn, 2016). Indeed, several members of the serine protease group, a widely distributed set of extracellular and intracellular proteolytic enzymes, act as pathogenicity factors in different plant pathogens including fungi, oomycetes, bacteria, insects, and nematodes (Ryan, 1990; Urwin et al., 1995; Atkinson et al., 2003; Gvozdeva et al., 2004; Lopez-Solanilla et al., 2004; Hermosa et al., 2006; Pekkarinen et al., 2007; Luo et al., 2009; Thomas and van der Hoorn, 2018). Besides, serine proteases also regulate a panoply of endogenous processes in plants including innate immunity, cell death and nitrogen uptake (Kohli et al., 2012; Grosse-Holz and van der Hoorn, 2016; Salvesen et al., 2016; Balakireva and Zamyatnin, 2018). Interestingly, inhibitors of these enzymes, especially those belonging to the multigene PI families PKPI and Pin 1 have been shown to accumulate in plant tissues in a highly precise spatial and temporal manner and following both abiotic and biotic threats (Hermosa et al., 2006; Wang et al., 2008; Singh et al., 2009; Turrà et al., 2009; Boex-Fontvieille et al., 2015; Rustgi et al., 2017). These findings together with the increasing evidence of their inhibitory activity both in vitro and in vivo toward insects and nematodes, and in vitro toward fungi and bacteria is indicative of a possible multitasking activity of these PI families in both the regulation of plant physiology and biochemical defense responses (Duan et al., 1996; Cai et al., 2003; Vila et al., 2005; Turrà and Lorito, 2011; Quilis et al., 2013). However, a clear correlation between PKPI and Pin1 expression and in planta modulation of developmental processes or resistance toward fungal or bacterial pathogens is currently missing. We have previously shown that extracellular proteases secreted by the fungal pathogen $B$. cinerea mainly belong to the serine protease class (Hermosa et al., 2006). We further identified, from the complex set of plant-produced PIs, different protein products belonging to the PKPI and Pin 1 serine proteinase inhibitor families and showing high inhibitory activity on both fungal growth and disease development when exogenously supplemented to the fungal inoculum source (Hermosa et al., 2006). Now, to demonstrate their efficacy in vivo toward fungal plant pathogens, we have heterologously expressed different potato PKPI and Pin1 genes in $N$. benthamiana, a model system to study the effect of transgene expression on plant-pathogen interactions (Goodin et al., 2008). Consistent with our previous findings, all tested PIs genes (except the Pin1 PPI3A2) efficiently reduced the in vitro growth and increased plant resistance toward two fungal pathogens, $B$. cinerea and A. alternata. Noteworthy, no B. cinerea symptoms developed at all, even 6 days postinoculation, on $N$. benthamiana plants transformed with PPI3B2, the potato Pin1 inhibitor formerly identified for its strong antifungal activity on B. cinerea in vitro (Hermosa et al., 2006). To understand if in planta over-expression of PKPI and Pin1 genes could also alter plant resistance toward bacterial phytopathogens, we challenged $N$. benthamiana transformed plants with the bacterial pathogen $P$. syringae pv. tabaci. Interestingly, bacteria survival in PKI2-, PPI3A2-, PPI3B2-, and PPI2C4-expressing plants dropped over time and necrotic symptoms barely developed on PKI2 and PPI2C4 transformed leaves, suggesting that PKPI and Pin1 PIs might act by exerting either a direct and/or indirect 
antiproliferative activity on Pseudomonas. This hypothesis is supported by two lines of evidence. First, several studies have already shown the importance of Pseudomonas spp. cysteine and serine proteases in the degradation of both structural and soluble host plant proteins and virulence (Engel et al., 1998; Axtell et al., 2003; Hotson and Mudgett, 2004). Second, uninfected PKI2-, and PPI2C4-transformed areas from fully developed leaves enlarged abruptly and accumulated higher amounts of trichomes, epidermal cells specialized in defending the plant from both biotic and abiotic stresses (Wagner, 1991; Amme et al., 2005). Importantly, this phenotype was accompanied by an increase in epidermial cell growth and division in PVX:PPI2C4 agroinfiltrated leaves and an overall shoot and root size in systemically transformed plants, indicative for an endogenous inhibitory activity of these PIs, as also shown by TSP activity on apoplastic proteases.

Overall our findings show for the first time that specific members of the Pin1 and PKPI PI families might act as multifunctional proteins playing fundamental roles in both the regulation of important plant physiological processes such as cell development and differentiation as well as wide-spectrum disease resistance against fungal and bacterial pathogens. These results might represent a framework for the future selection of Pin 1 and PKPI genes to be used either individually or in gene pyramiding approaches to obtain fast-growing trees or crops with broad-resistance to biotic threats.

\section{DATA AVAILABILITY STATEMENT}

All datasets generated for this study are included in the article/Supplementary Material.

\section{REFERENCES}

Altpeter, F., Diaz, I., McAuslane, H., Gaddour, K., Carbonero, P., and Vasil, I. (1999). Increased insect resistance in transgenic wheat stably expressing trypsin inhibitor CMe. Mol. Breed. 5, 53-63. doi: 10.1023/A:1009659911798

Amme, S., Rutten, T., Melzer, M., Sonsmann, G., Vissers, J. P., Schlesier, B., et al. (2005). A proteome approach defines protective functions of tobacco leaf trichomes. Proteomics 5, 2508-2518. doi: 10.1002/pmic.200401274

Andrade, S. A., Santomauro-Vaz, E. M., Lopes, A. R., Chudzinski-Tavassi, A. M., Juliano, M. A., Terra, W. R., et al. (2003). Bauhinia proteinase inhibitor-based synthetic fluorogenic substrates for enzymes isolated from insect midgut and caterpillar bristles. Biol. Chem. 384, 489-492.

Atkinson, H. J., Urwin, P. E., and McPherson, M. J. (2003). Engineering plants for nematode resistance. Annu. Rev. Phytopathol. 41, 615-639.

Axtell, M. J., Chisholm, S. T., Dahlbeck, D., and Staskawicz, B. J. (2003). Genetic and molecular evidence that the Pseudomonas syringae type III effector protein AvrRpt2 is a cysteine protease. Mol. Microbiol. 49, 1537-1546. doi: 10.1046/j. 1365-2958.2003.03666.x

Balakireva, A. V., and Zamyatnin, A. A. (2018). Indispensable role of proteases in plant innate immunity. Int. J. Mol. Sci. 19:629. doi: 10.3390/ijms19020629

Balandin, T., van der Does, C., Albert, J. M., Bol, J. F., and Linthorst, H. J. (1995). Structure and induction pattern of a novel proteinase inhibitor class II gene of tobacco. Plant Mol. Biol. 27, 1197-1204. doi: 10.1007/bf00020893

Boex-Fontvieille, E., Rustgi, S., Reinbothe, S., and Reinbothe, C. (2015). A Kunitz-type protease inhibitor regulates programmed cell death during flower development in Arabidopsis thaliana. J. Exp. Bot. 66, 6119-6135. doi: 10.1093/ jxb/erv327

\section{AUTHOR CONTRIBUTIONS}

DT, SV, SW, and ML designed and conceived the study, and wrote the manuscript. DT, SV, and RM performed the experiments and analyzed the data. All authors read and approved the final version of the manuscript for publication.

\section{FUNDING}

This work was supported by the following projects: MIURPON (Grant No. Linfa 03PE_00026_1; Grant No. Marea 03PE_00106); MIUR-GPS (Grant No. Sicura DM29156); POR FESR CAMPANIA 2014/2020- O.S. 1.1 (Grant No. Bioagro CUP B63D18000270007); MISE (Grant No. Protection F/050421/0103/X32); PRIN 2017 (Grant No. PROSPECT 2017JLN833); Regione Veneto PSR 2014-2020 (Grant No. DIVINE 3589659) and Regione Campania PSR 2014-2020 (Grant No. ABC 2015.15.17221.5692).

\section{ACKNOWLEDGMENTS}

We gratefully thank D. Baulcombe (Sainsbury Laboratory, Norwich, United Kingdom) for the PVX-based expression vectors pgR106 and pgR208 and the A. tumefaciens strain GV3101.

\section{SUPPLEMENTARY MATERIAL}

The Supplementary Material for this article can be found online at: https://www.frontiersin.org/articles/10.3389/fpls.2020.00461/ full\#supplementary-material

Cai, D., Thurau, T., Tian, Y., Lange, T., Yeh, K. W., and Jung, C. (2003). Sporaminmediated resistance to beet cyst nematodes (Heterodera schachtii Schm.) is dependent on trypsin inhibitory activity in sugar beet (Beta vulgaris L.) hairy roots. Plant Mol. Biol. 51, 839-849.

Chen, Z. Y., Brown, R. L., Lax, A. R., Cleveland, T. E., and Russin, J. S. (1999). Inhibition of plant-pathogenic fungi by a corn trypsin inhibitor overexpressed in Escherichia coli. Appl. Environ. Microbiol. 65, 1320-1324. doi: 10.1128/aem. 65.3.1320-1324.1999

Collins, T. J. (2007). ImageJ for microscopy. Biotechniques 43(1 Suppl.), 25-30.

Di Cera, E. (2009). Serine proteases. IUBMB Life 61, 510-515. doi: 10.1002/iub.186

Duan, X., Li, X., Xue, Q., Abo-el-Saad, M., Xu, D., and Wu, R. (1996). Transgenic rice plants harboring an introduced potato proteinase inhibitor II gene are insect resistant. Nat. Biotechnol. 14, 494-498. doi: 10.1038/nbt0496-494

Dunaevsky, Y. E., Pavlukova, E. B., and Belozersky, M. A. (1996). Isolation and properties of anionic protease inhibitors from buckwheat seeds. Biochem. Mol. Biol. Int. 40, 199-208. doi: 10.1080/15216549600201692

Emanuelsson, O., Brunak, S., von Heijne, G., and Nielsen, H. (2007). Locating proteins in the cell using TargetP, SignalP and related tools. Nat. Protoc. 2, 953-971. doi: 10.1038/nprot.2007.131

Engel, L. S., Hill, J. M., Caballero, A. R., Green, L. C., and O'Callaghan, R. J. (1998). Protease IV, a unique extracellular protease and virulence factor from Pseudomonas aeruginosa. J. Biol. Chem. 273, 16792-16797. doi: 10.1074/jbc. 273.27.16792

Gevaudant, F., Duby, G., von Stedingk, E., Zhao, R., Morsomme, P., and Boutry, M. (2007). Expression of a constitutively activated plasma membrane H+ATPase alters plant development and increases salt tolerance. Plant Physiol. 144, 1763-1776. doi: 10.1104/pp.107.103762 
Goodin, M. M., Zaitlin, D., Naidu, R. A., and Lommel, S. A. (2008). Nicotiana benthamiana: its history and future as a model for plant-pathogen interactions. Mol. Plant Microbe Interact. 21, 1015-1026. doi: 10.1094/mpmi-21-8-1015

Grosse-Holz, F. M., and van der Hoorn, R. A. L. (2016). Juggling jobs: roles and mechanisms of multifunctional protease inhibitors in plants. New Phytol. 210, 794-807. doi: 10.1111/nph.13839

Gvozdeva, E. L., Ievleva, E. V., Gerasimova, N. G., Ozeretskovskaia, O. L., and Valueva, T. A. (2004). Exoproteinases of the oomycete Phytophthora infestans. Prikl. Biokhim. Mikrobiol. 40, 194-200.

Heibges, A., Glaczinski, H., Ballvora, A., Salamini, F., and Gebhardt, C. (2003). Structural diversity and organization of three gene families for Kunitz-type enzyme inhibitors from potato tubers (Solanum tuberosum L.). Mol. Genet. Genomics 269, 526-534. doi: 10.1007/s00438-003-0860-0

Heitz, T., Geoffroy, P., Stintzi, A., Fritig, B., and Legrand, M. (1993). cDNA cloning and gene expression analysis of the microbial proteinase inhibitor of tobacco. J. Biol. Chem. 268, 16987-16992.

Hermosa, M. R., Turrà, D., Fogliano, V., Monte, E., and Lorito, M. (2006). Identification and characterization of potato protease inhibitors able to inhibit pathogenicity and growth of Botrytis cinerea. Physiol. Mol. Plant Pathol. 68, 138-148. doi: 10.1016/j.pmpp.2006.09.004

Horton, P., Park, K. J., Obayashi, T., Fujita, N., Harada, H., Adams-Collier, C. J., et al. (2007). WoLF PSORT: protein localization predictor. Nucleic Acids Res. 35, W585-W587. doi: 10.1093/nar/gkm259

Hotson, A., and Mudgett, M. B. (2004). Cysteine proteases in phytopathogenic bacteria: identification of plant targets and activation of innate immunity. Curr. Opin. Plant Biol. 7, 384-390. doi: 10.1016/j.pbi.2004.05.003

Jofuku, K. D., and Goldberg, R. B. (1989). Kunitz trypsin inhibitor genes are differentially expressed during the soybean life cycle and in transformed tobacco plants. Plant Cell 1, 1079-1093. doi: 10.1105/tpc.1.11.1079

Jongsma, M. A., Bakker, P. L., Peters, J., Bosch, D., and Stiekema, W. J. (1995). Adaptation of Spodoptera exigua larvae to plant proteinase inhibitors by induction of gut proteinase activity insensitive to inhibition. Proc. Natl. Acad. Sci. U.S.A. 92, 8041-8045. doi: 10.1073/pnas.92.17.8041

Keller, C. P., and Van Volkenburgh, E. (1997). Auxin-induced epinasty of tobacco leaf tissues (a nonethylene-mediated response). Plant Physiol. 113, 603-610. doi: 10.1104/pp.113.2.603

Kim, J. Y., Park, S. C., Kim, M. H., Lim, H. T., Park, Y., and Hahm, K. S. (2005). Antimicrobial activity studies on a trypsin-chymotrypsin protease inhibitor obtained from potato. Biochem. Biophys. Res. Commun. 330, 921-927. doi: 10.1016/j.bbrc.2005.03.057

Kim, M. H., Park, S. C., Kim, J. Y., Lee, S. Y., Lim, H. T., Cheong, H., et al. (2006). Purification and characterization of a heat-stable serine protease inhibitor from the tubers of new potato variety "Golden Valley". Biochem. Biophys. Res. Commun. 346, 681-686. doi: 10.1016/j.bbrc.2006.05.186

Kohli, A., Narciso, J. O., Miro, B., and Raorane, M. (2012). Root proteases: reinforced links between nitrogen uptake and mobilization and drought tolerance. Physiol. Plant 145, 165-179. doi: 10.1111/j.1399-3054.2012.01573.x

Kuo, T. M., Pearce, G., and Ryan, C. A. (1984). Isolation and characterization of proteinase inhibitor I from etiolated tobacco leaves. Arch. Biochem. Biophys. 230, 504-510. doi: 10.1016/0003-9861(84)90430-2

Lee, J. S., Brown, W. E., Graham, J. S., Pearce, G., Fox, E. A., Dreher, T. W., et al. (1986). Molecular characterization and phylogenetic studies of a woundinducible proteinase inhibitor I gene in Lycopersicon species. Proc. Natl. Acad. Sci. U.S.A. 83, 7277-7281. doi: 10.1073/pnas.83.19.7277

Lincoln, J. E., Cordes, S., Read, E., and Fischer, R. L. (1987). Regulation of gene expression by ethylene during Lycopersicon esculentum (tomato) fruit development. Proc. Natl. Acad. Sci. U.S.A. 84, 2793-2797. doi: 10.1073/pnas. 84.9.2793

Liu, J., Xia, K. F., Zhu, J. C., Deng, Y. G., Huang, X. L., Hu, B. L., et al. (2006). The nightshade proteinase inhibitor IIb gene is constitutively expressed in glandular trichomes. Plant Cell Physiol. 47, 1274-1284. doi: 10.1093/pcp/pcj097

Lopez-Solanilla, E., Bronstein, P. A., Schneider, A. R., and Collmer, A. (2004). HopPtoN is a Pseudomonas syringae Hrp (type III secretion system) cysteine protease effector that suppresses pathogen-induced necrosis associated with both compatible and incompatible plant interactions. Mol. Microbiol. 54, 353365. doi: 10.1111/j.1365-2958.2004.04285.x

Lorito, M., Broadway, R. M., Hayes, C. K., Woo, S. L., Noviello, C., Williams, D. L., et al. (1994). Proteinase inhibitors from plants as a novel class of fungicides. Mol. Plant Microbe Interact. 7, 525-527.
Lu, R., Malcuit, I., Moffett, P., Ruiz, M. T., Peart, J., Wu, A. J., et al. (2003). High throughput virus-induced gene silencing implicates heat shock protein 90 in plant disease resistance. EMBO J. 22, 5690-5699. doi: 10.1093/emboj/cdg546

Luo, Y., Caldwell, K. S., Wroblewski, T., Wright, M. E., and Michelmore, R. W. (2009). Proteolysis of a negative regulator of innate immunity is dependent on resistance genes in tomato and Nicotiana benthamiana and induced by multiple bacterial effectors. Plant Cell 21, 2458-2472. doi: 10.1105/tpc.107.056044

Mello, G. C., Oliva, M. L., Sumikawa, J. T., Machado, O. L., Marangoni, S., Novello, J. C., et al. (2001). Purification and characterization of a new trypsin inhibitor from Dimorphandra mollis seeds. J. Protein Chem. 20, 625-632.

Moehnke, M. H., Midoro-Horiuti, T., Goldblum, R. M., and Kearney, C. M. (2008). The expression of a mountain cedar allergen comparing plant-viral apoplastic and yeast expression systems. Biotechnol. Lett. 30, 1259-1264. doi: 10.1007/ s10529-008-9665-x

Pak, C., and Van Doorn, W. G. (2005). Delay of Iris flower senescence by protease inhibitors. New Phytol. 165, 473-480. doi: 10.1111/j.1469-8137.2004.01226.x

Pekkarinen, A. I., Longstaff, C., and Jones, B. L. (2007). Kinetics of the inhibition of fusarium serine proteinases by barley (Hordeum vulgare L.) inhibitors. J. Agric. Food Chem. 55, 2736-2742. doi: 10.1021/jf0631777

Quilis, J., Lopez-Garcia, B., Meynard, D., Guiderdoni, E., and San Segundo, B. (2013). Inducible expression of a fusion gene encoding two proteinase inhibitors leads to insect and pathogen resistance in transgenic rice. Plant Biotechnol. J. 12, 367-377. doi: 10.1111/pbi.12143

Rairdan, G. J., Collier, S. M., Sacco, M. A., Baldwin, T. T., Boettrich, T., and Moffett, P. (2008). The coiled-coil and nucleotide binding domains of the Potato Rx disease resistance protein function in pathogen recognition and signaling. Plant Cell 20, 739-751. doi: 10.1105/tpc.107.056036

Rawlings, N. D., Tolle, D. P., and Barrett, A. J. (2004). Evolutionary families of peptidase inhibitors. Biochem. J. 378(Pt 3), 705-716. doi: 10.1042/bj20031825

Rawlings, N. D., Waller, M., Barrett, A. J., and Bateman, A. (2014). MEROPS: the database of proteolytic enzymes, their substrates and inhibitors. Nucleic Acids Res. 42, D503-D509. doi: 10.1093/nar/gkt953

Rosahl, S., Eckes, P., Schell, J., and Willmitzer, L. (1986). Organ-specific gene expression in potato: isolation and characterization of tuber-specific cDNA sequences. Mol. Gen. Genet. 202, 368-373. doi: 10.1007/bf00333264

Rustgi, S., Boex-Fontvieille, E., Reinbothe, C., von Wettstein, D., and Reinbothe, S. (2017). Serpin 1 and WSCP differentially regulate the activity of the cysteine protease RD21 during plant development in Arabidopsis thaliana. Proc. Natl. Acad. Sci. U.S.A. 114, 2212-2217. doi: 10.1073/pnas.1621496114

Ryan, C. A. (1990). Protease inhibitors in plants: genes for improving defenses against insects and pathogens. Annu. Rev. Phytopathol. 28, 425-449. doi: 10. 1146/annurev.py.28.090190.002233

Salvesen, G. S., Hempel, A., and Coll, N. S. (2016). Protease signaling in animal and plant-regulated cell death. FEBS J. 283, 2577-2598. doi: 10.1111/febs.13616

Sambrook, J., and Russell, D. W. (2001). Molecular Cloning: A Laboratory Manual. Cold Spring Harbor, NY: Cold Spring Harbor Laboratory Press.

Sin, S. F., and Chye, M. L. (2004). Expression of proteinase inhibitor II proteins during floral development in Solanum americanum. Planta 219, 1010-1022. doi: 10.1007/s00425-004-1306-6

Singh, A., Sahi, C., and Grover, A. (2009). Chymotrypsin protease inhibitor gene family in rice: Genomic organization and evidence for the presence of a bidirectional promoter shared between two chymotrypsin protease inhibitor genes. Gene 428, 9-19. doi: 10.1016/j.gene.2008.09.028

Soares-Costa, A., Beltramini, L. M., Thiemann, O. H., and Henrique-Silva, F. (2002). A sugarcane cystatin: recombinant expression, purification, and antifungal activity. Biochem. Biophys. Res. Commun. 296, 1194-1199. doi: 10.1016/s0006-291x(02)02046-6

Solomon, M., Belenghi, B., Delledonne, M., Menachem, E., and Levine, A. (1999). The involvement of cysteine proteases and protease inhibitor genes in the regulation of programmed cell death in plants. Plant Cell 11, 431-444.

Srinivasan, A., Giri, A. P., Harsulkar, A. M., Gatehouse, J. A., and Gupta, V. S. (2005). A Kunitz trypsin inhibitor from chickpea (Cicer arietinum L.) that exerts anti-metabolic effect on podborer (Helicoverpa armigera) larvae. Plant Mol. Biol. 57, 359-374. doi: 10.1007/s11103-004-7925-2

Tamhane, V. A., Giri, A. P., Kumar, P., and Gupta, V. S. (2009). Spatial and temporal expression patterns of diverse Pin-II proteinase inhibitor genes in Capsicum annuum Linn. Gene 442, 88-98. doi: 10.1016/j.gene.2009.04.012

Thomas, E. L., and van der Hoorn, R. A. L. (2018). Ten prominent host proteases in plant-pathogen interactions. Int. J. Mol. Sci. 19:639. doi: 10.3390/ijms19020639 
Tian, M., Huitema, E., Da Cunha, L., Torto-Alalibo, T., and Kamoun, S. (2004). A Kazal-like extracellular serine protease inhibitor from Phytophthora infestans targets the tomato pathogenesis-related protease P69B. J. Biol. Chem. 279, 26370-26377. doi: 10.1074/jbc.m400941200

Turrà, D., Bellin, D., Lorito, M., and Gebhardt, C. (2009). Genotypedependent expression of specific members of potato protease inhibitor gene families in different tissues and in response to wounding and nematode infection. J. Plant Physiol. 166, 762-774. doi: 10.1016/j.jplph.2008.1 0.005

Turrà, D., and Lorito, M. (2011). Potato type I and II proteinase inhibitors: modulating plant physiology and host resistance. Curr. Protein Pept. Sci. 12, 374-385. doi: 10.2174/138920311796391151

Urwin, P. E., Atkinson, H. J., Waller, D. A., and McPherson, M. J. (1995). Engineered oryzacystatin-I expressed in transgenic hairy roots confers resistance to Globodera pallida. Plant J. 8, 121-131. doi: 10.1046/j.1365-313x. 1995.08010121.x

van den Broek, L. A., Pouvreau, L., Lommerse, G., Schipper, B., Van Koningsveld, G. A., and Gruppen, H. (2004). Structural characterization of potato protease inhibitor I (Cv. Bintje) after expression in Pichia pastoris. J. Agric. Food Chem. 52, 4928-4934.

van der Hoorn, R. A. (2008). Plant proteases: from phenotypes to molecular mechanisms. Annu. Rev. Plant Biol. 59, 191-223. doi: 10.1146/annurev.arplant. 59.032607.092835

van Loon, L. C., Rep, M., and Pieterse, C. M. (2006). Significance of inducible defense-related proteins in infected plants. Annu. Rev. Phytopathol. 44, 135162. doi: 10.1146/annurev.phyto.44.070505.143425

Vila, L., Quilis, J., Meynard, D., Breitler, J. C., Marfa, V., Murillo, I., et al. (2005). Expression of the maize proteinase inhibitor (mpi) gene in rice plants enhances resistance against the striped stem borer (Chilo suppressalis): effects on larval growth and insect gut proteinases. Plant Biotechnol. J. 3, 187-202. doi: 10.1111/ j.1467-7652.2004.00117.x

Wagner, G. J. (1991). Secreting glandular trichomes: more than just hairs. Plant Physiol. 96, 675-679. doi: 10.1104/pp.96.3.675

Wang, H. Y., Huang, Y. C., Chen, S. F., and Yeh, K. W. (2003). Molecular cloning, characterization and gene expression of a water deficiency and chilling induced proteinase inhibitor I gene family from sweet potato (Ipomoea batatas Lam.) leaves. Plant Sci. 165, 191-203. doi: 10.1016/s0168-9452(03)00158-4

Wang, J., Shi, Z. Y., Wan, X. S., Shen, G. Z., and Zhang, J. L. (2008). The expression pattern of a rice proteinase inhibitor gene OsPI8-1 implies its role in plant development. J. Plant Physiol. 165, 1519-1529. doi: 10.1016/j.jplph.2007.08.008

Xie, J., Ouyang, X. Z., Xia, K. F., Huang, Y. F., Pan, W. B., Cai, Y. P., et al. (2007). Chloroplast-like organelles were found in enucleate sieve elements of transgenic plants overexpressing a proteinase inhibitor. Biosci. Biotechnol. Biochem. 71, 2759-2765. doi: 10.1271/bbb.70362

Xu, Z. F., Qi, W. Q., Ouyang, X. Z., Yeung, E., and Chye, M. L. (2001). A proteinase inhibitor II of Solanum americanum is expressed in phloem. Plant Mol. Biol. 47, 727-738.

Conflict of Interest: The authors declare that the research was conducted in the absence of any commercial or financial relationships that could be construed as a potential conflict of interest.

Copyright (C) 2020 Turrà, Vitale, Marra, Woo and Lorito. This is an open-access article distributed under the terms of the Creative Commons Attribution License (CC BY). The use, distribution or reproduction in other forums is permitted, provided the original author(s) and the copyright owner(s) are credited and that the original publication in this journal is cited, in accordance with accepted academic practice. No use, distribution or reproduction is permitted which does not comply with these terms. 